\title{
Discourses of healthcare professionals about health surveillance actions for Tuberculosis control*
}

\author{
Discursos dos profissionais de saúde sobre ações de \\ vigilância em saúde no controle da tuberculose \\ Discursos de los profesionales sanitarios sobre acciones de \\ vigilancia sanitaria en el control de la tuberculosis
}

Fernando Mitano ${ }^{1}$, Amélia Nunes Sicsú ${ }^{2}$, Luciana de Oliveira Sousa², Laís Mara Caetano da Silva², Pedro Fredemir Palha²

How to cite this article:

Mitano F, Sicsú AN, Sousa LO, Silva LMC, Palha PF. Discourses of healthcare professionals about health surveillance actions for Tuberculosis control. Rev Esc Enferm USP. 2017;51:e03213. DOI: http://dx.doi.org/10.1590/S1980-220X2016018203213

* Extracted from the thesis "Discursos e produção de sentidos: experiência da transferência da política do tratamento diretamente observado de curta duração para o controle da tuberculose em Moçambique - África”, Programa de Pós-Graduação Enfermagem em Saúde Pública, Escola de Enfermagem de Ribeirão Preto, Universidade de São Paulo, 2016.

${ }^{1}$ Universidade Lúrio, Mozambique.

${ }^{2}$ Universidade de São Paulo, Escola de Enfermagem de Ribeirão Preto, Departamento Materno-Infantil e Saúde Pública, Ribeirão Preto, SP, Brazil.

\section{ABSTRACT}

Objective: To analyze the meanings produced in the Health Surveillance actions for tuberculosis control, carried out by healthcare professionals in Mozambique. Method: Qualitative study using the theoretical and methodological framework of the French Discourse Analysis. Results: A total of 15 healthcare professionals with more than one year of experience in disease control actions participated in the study. Four discursive blocks have emerged from the analysis: tuberculosis diagnosis process; meeting, communication and discussion of treatment; local strategies for tuberculosis control; involvement of family and community leaders in the tuberculosis control. Conclusion: The statements of the healthcare professionals suggest, as Health Surveillance actions, practices that include collecting sputum in the patient's home and sending it to the laboratory; deployment of the medical team with a microscope for tuberculosis testing; and testing for diseases that may be associated with tuberculosis. In this context, the actions of Health Surveillance for tuberculosis control involve valuing all actors: family, community leaders, patients and health professionals.

\section{DESCRIPTORS}

Tuberculosis; Health Surveillance; Mozambique; Public Health Nursing; Health Services.

\section{Corresponding author:}

Fernando Mitano

Universidade Lúrio, Mozambique

Faculdade de Ciências de Saúde

Campus de Marrere

Street No. 4250, Km 2,3

Mailbox, 364; Nampula, Mozambique

piqinamita@gmail.com
Received: 05/16/2016

Approved: 01/04/2017 


\section{INTRODUCTION}

Health Surveillance actions for the control of tuberculosis (TB) - a disease that remains as one of the main public health problems in the world, especially in low-income countries such as Mozambique - are one of the most important elements in the fight against the disease. Mozambique is one of the countries most affected by tuberculosis, with an incidence of 552/100,000 inhabitants, ranking third among the 22 countries responsible for $80 \%$ of the TB cases in the world $^{(1-2)}$. It is estimated that around 140,000 new cases occur annually in the country ${ }^{(1)}$.

TB is one of the main causes of death in this country, accounting for $3.1 \%$ of all deaths, which is considered above the average for the African continent in $2011^{(3)}$. The World Health Organization (WHO) has stated that there is no possibility of reducing the incidence, prevalence and mortality indicators of the disease in Mozambique due to lack of resources and the HIV pandemic ${ }^{(1-2,4)}$. This situation has contributed to the increase of the disease in that country. However, despite the alarming situation, there are, in that context, surveillance actions carried out by healthcare professionals, which contribute to the control of tuberculosis, although, they need approval and expansion for the entire population. It should be noted that the TB Control Program in Mozambique follows WHO guidelines and is mainly based on the quick identification of cases and subsequent treatment ${ }^{(1)}$.

In the context described, surveillance actions are of paramount importance for the control of TB. The goal of the Health Surveillance (HS) is to permanently observe and analyze the health situation of the population and, articulating with health services, which must be prepared to identify diseases and aggravations early, establish pertinent actions, enabling activities to promote health and prevent diseases and aggravations ${ }^{(5)}$.

Therefore, HS is considered to be an important model for monitoring the health situation. It contributes to TB control when it seeks to transform and enable the work processes in health, transcending the health services spaces, using territorialities as an instrument to recognize where the population lives and works. In this regard, HS proposes an expanded understanding of the population's health care and stimulates interventions in the determinants of $\mathrm{TB}^{(6)}$.

HS actions can contribute to the control of the disease, considering the work of the team of healthcare professionals is done according to each local reality, as health professionals are inserted in the community and carry out activities with the population, such as health education, searches for respiratory symptoms, observation of medication intake, monitoring of contacts, searching for absentees, among other actions that leave the individual scope and become collective, thus generating an improvement in the access to health services, diagnosis and treatment of TB patients ${ }^{(6-7)}$.

Therefore, it is important to explore the meanings produced by professionals about the actions of HS performed in a country with high TB burden, since the comprehension of these meanings can contribute to the elaboration of strategies that involve the local conditions for the production of TB control and to the use of new disease control practices in Mozambique and in countries with similar characteristics. In this regard, this study aims to analyze the meanings produced in the Health Surveillance actions for tuberculosis control, carried out by healthcare professionals in Mozambique

\section{METHOD}

This is a qualitative study using the theoretical and methodological support of the French Discourse Analysis (DA), which epistemologically merges into a linguistic, materialistic and psychoanalytic philosophy ${ }^{(8)}$. DA is a realization of the ideology originated from the social modes of produc$\operatorname{tion}^{(8-9)}$. Through the speech one understands the meanings produced in function of the discursive formations of a given ideology. In discourse analysis, it is possible to understand the individual and collective speech, and this can bring elements that help in the identification of the ways of acting in health. Discourse analysis sees "language as the necessary mediation between man and the natural and social reality"(8). This mediation allows men to transform themselves and give meaning to reality. The meanings, this way, are determined relations of the individual that is affected by language in history. Therefore, the meanings are not predetermined, signifying that words change meaning according to the discursive formation ${ }^{(8-9)}$.

The study was carried out in Mozambique, in the Ministry of Health (central level) and in the province of Nampula (provincial level) in the districts of Mecubúri, Muecate, Nampula-Rapale, Ribaué, Murrupula, Meconta, Mogovolas and Monapo in the period between May and August 2014. Fifteen subjects were interviewed: managers (at different levels of the Mozambique health system: central, provincial or district), physicians, nursing professionals and healthcare team technicians from the districts listed above, who have met the following criteria: working for more than 1 year in the National Tuberculosis Control Program (NTCP) and being in activity at the time of data collection.

For data collection, two interview scripts were elaborated: one applied to the managers, the other to the physicians, nursing professionals and technicians. The interviewees were contacted individually by the researchers and the purposes of the research were explained. After the acceptance, the interviews were scheduled by mutual agreement. These were audiotaped and happened in places defined by the interviewees.

The data was organized using Atlas. Ti software, version 6.0. This software facilitates the organization of qualitative data from open and semi-structured interviews, including audio, picture and video data, in a systematized way. After several readings of the material, and based on the objectives of the study, the interviews transcribed and saved in a Word document were archived in $\mathrm{rtf}$ format and then housed in the Atlas.Ti software, where quotes (codes) were created conformed in the discursive sequences under analysis. After that, the statements (speeches) that were part of the codes 
created were identified. After being identified and selected, the lines were assigned to the codes. In this way, the Atlas. Ti software did not interfere in the choice of speeches nor in the creation of quotes, but merely assisted in the organization of the data.

In order to build the corpus, the speeches considered were aligned with the objective of the research, the conditions of production and the existing ideological processes. In this context, a heterogeneity of the linguistic material contributed to creating the meaning effects. Thus, the linguistic marks for analysis are constituted by syntactic constructions and lexical and morphological elements, not restricted to a single kind of material ${ }^{(10)}$.

To analyze the data, the study was based on an evidential paradigm, which consists in identifying clues that allow grasping a deeper understanding of reality, otherwise unattainable ${ }^{(11)}$. To find the clues and interpret them, the following steps were followed:

The first step - going from the linguistic surface to the discursive object-, was the transcription of the audiotaped interviews. After the transcription, several readings were made to identify the ideas to assemble the cutouts for the discursive blocks. From the linguistic surface, the discursiveness was identified, thus constructing a discursive object. In this way, the relation of what was said to what wasn't said and what could have been said, became visible. In the second phase - from the discursive object to the discursive process - the signifiers or discursive sequences with an important role in the production of meanings were identified, regarding the process of signification with the ideological formation that may be behind these relations. In this phase, relating the different discursive formations was also sought. In the third and last phase - discursive process itself (ideological formation) - a return was made to the sequences that constitute the object of analysis, integrating them with the existing theory on the subject under study. Therefore, it was possible to weave the intricate relations of discourse, language, subject and meanings articulated to the ideology and to the unconscious. In this way, the confrontation of the different participants was assured by central ideas, thus comprising the meanings produced ${ }^{(8)}$.

The interpretations made in this study do not exclude others, but merely show the clues of what was understood through the archives of the researchers. This argument gains value because the discourse is permeated by several voices, allowing the possibility of multiple interpretations, based on the conditions of production in which it was generated ${ }^{(8)}$.

This research was approved by Mozambican National Ethics Committee (CNBS - Comitê Nacional de Bioética para Saude) in April 2014 (reference number 87/CNBS/2014), and registered in the same Committee with the number 03/ $\mathrm{CNBS} / 2014$. It was also authorized by the Mozambican Minister of Health, with the number 731/GMS/002/2014. It should be noted that the anonymity of the research participants was preserved, organizing them through the following codes: M, Manager; PNM, Professional Nursing Manager; NP, Nursing Professional; P, Physician; And T, Technician.

\section{RESULTS}

The discursive sequences that produce meanings related to health surveillance actions for TB control performed by health professionals constitute the corpus for analysis. For the analysis, four discursive blocks were identified: TB diagnosis process; meeting, communication and discussion of TB treatment; strategies for TB control; involvement of family and community leaders in TB control. All subjects who participated in the study (15) were aged between 18 and 55 years old. Five of them had undergraduate level, and the others had technical or high school level.

Regarding the TB diagnosis process, the healthcare professionals' positions as individuals state the prevailing mode of diagnosis, as it can be seen in the following cuts:

We give spitters to the volunteers and they collect the samples that are observed and the results go there, and the treatment continues at a normal pace and then the dropouts decrease (PNM).

Then, when the time comes to control, they (Community Health Agent-ACS, in Portuguese: Agente Comunitário de Saúde) collect the samples, bring them here (sanitary unit where the samples are observed), we observe, give results and the treatment continues at home, that's what we call community $\operatorname{DOTS}(\mathrm{NP})$.

Other actions on the diagnostic process were described by research subjects in the following cutouts:

On coughing days we go out with the man from the lab (in brigade) to a village and start the screening and during this period we are able to detect more cases. I go out with the man from the lab, because he's the one who makes the smears and everything (PNM).

They bring it here and we submit it for analysis in the lab. If it's positive, I go there. I take the scale, the HIV test, I test them and we open the files and the volunteer (ACS) comes here to gather the medicines (NP).

Regarding the discursive block meeting, communication and discussion of treatment, the healthcare professionals considered the communication strategy as important in the exchange of information and acquisition of knowledge, as it is enunciated, discursively, between the lines in the cutouts that follow:

We meet with all the health units monthly and the colleagues of these units bring statistics, we coordinate, correct what is wrong and what is right we validate immediately $(\mathrm{M})$. Quarterly we meet and discuss a lot about the cases (M). We hold meetings and discussions of our activities to motivate others (PNM). Every 30 days we've been having a meeting, after the general statistics we have some time to talk about TB (M). We discuss first among ourselves on Wednesdays and with the volunteers on the third day of each month, until last month we went to the meeting with our laboratory man (PNM).

The participation of non-governmental organizations and the implementation of actions that motivate community healthcare agents are regarded as local strategies for TB control. The following statements of the healthcare professional subjects enunciate these strategies. 
The organization called Kulima (name of a non-governmental organization based in the city of Nampula) (...) brings dishes, capulanas (a name given to a type of cloth that Mozambican women use to bind the body, sometimes using it as a skirt, or turban) to distribute to activists. So I offer those to the activists and this motivates them to stay in the program (PNM).

Another strategy used by healthcare professionals in the fight against TB is creating communities:

We create (...) communities, where we treat the sick (PNM). They (volunteers and multipurpose agents) live in the communities, identify people who have a cough for more than a week or two and bring them to the health unit $(\mathrm{T})$.

The search for respiratory symptoms is understood as important for short-term therapy:

The direct observation treatment is innovative because we look for the patient in the community, back then we waited for the patients in the health unit, but now we go to them (NP).

The healthcare professional subject, taking the position of the manager subject, says:

I have to go through each health unit every week or every quarter and raise awareness among my colleagues, because a lot of my colleagues think that being in the TB program is about money, it used to be, but now things have changed a lot (M).

The involvement of family and community leaders in TB control has been one of the actions carried out intensively by healthcare professionals, as evidenced by the following cutouts:

We involve family members; the family members control the patient. That's the motivation. First, if the clinical condition of the patient is not serious we make a pact with the family and inform the care they should give the patient and the help they should provide him and this motivates the patient to take the medication until the end $(\mathrm{P})$.

The involvement of the patient has also been considered important for the control of TB by the healthcare professional subjects:

We contact the patient, talk to the patient, first because (...) the surrounding patients are not a problem, we contact the patients, we talk to them, because (...) first we ask or we try to know the family history, if they live with children, how many people they live with. Because, if the patient lives nearby, we ask him to come and see us for isoniazid prophylaxis (T).

After 15 days in treatment, when we see that the general condition of the patient is satisfactory, we contact the patient and talk to him and this dialogue is already a contract that we make with the patient. We explain that in the condition he is, there is no need to continue here (in the health unit where the patient was treated) for more than 45 days so he can continue the treatment at home, some accept that, some don't $(\mathrm{P})$.

The involvement of influential community leaders and the patient himself is one of the health actions for TB control in Mozambique:

We involve the community leaders and the population (PNM). In my case, whenever the patients come to take the pills I give them more information. Besides eveything I have done many times I must repeat it so they don't forget (M).

\section{DISCUSSION}

The results of this study suggest that healthcare professionals, when positioning themselves discursively, are enrolled in discursive formations that focus on diagnosis of the disease, treatment agreements, family participation and community leadership involvement, as well as strategies for adherence to TB treatment.

TB diagnosis is one of the actions done by Health Surveillance to control the disease ${ }^{(2,12)}$. In this context, from the production conditions in which the healthcare professionals were at the time of the interview, it is observed that the diagnostic actions for TB control are agreed between the professionals and the Community Health Agents (ACS), which facilitates the access of people affected by TB to health services. In addition, the ACS are translators of the cultural values of the community besides the scientific-medical knowledge, represented by healthcare professionals ${ }^{(13)}$.

It is understood that the discursive sequences they collect the samples; we observe; we give spitters suggest that TB screening actions are coordinated between professionals and $\mathrm{ACS}$, but, on the other hand, the same signifiers indirectly state the search for strategies of action by the healthcare professionals in face of the difficulties of the lack of professionals to care for TB patients. The lack of human resources has severely compromised TB treatment, considering Mozambique is one of the countries with a critical shortage of healthcare professionals (physician, nurses, technicians and administrative staff $)^{(14)}$. Still, the signifiers produce meanings of poor access to health facilities, a need that seems to prompt local health authorities to go to the communities to test suspects. The practice of collecting sputum in the patient's home done by the ACS is considered important for increasing diagnosis and access to treatment, in addition to increasing the rate of cases detected ${ }^{(15)}$. However, while these actions are necessary and of extreme importance to improve the health of the population, Mozambique has not attained the goals of reducing $\mathrm{TB}^{(4)}$.

The metaphor, defined as taking one word for another ${ }^{(8)}$, presented in the signifiers on coughing days, indicate the days when health workers mobilize to do TB screening in communities. The actions in go out with and start the screening suggest team work. In this context, the actions carried out by teams in the health services are considered to be more effective for patient care and for valuing community practices ${ }^{(16)}$. Resuming the analysis, the discourse sequence during this period we are able to detect more cases, produces meaning that the screening is done in a non-systematic way, with periods in which it doesn't happen, thus indicating there are cases unnotified in periods when healthcare professionals are not addressing such communities. In this context, the discursive sequence under analysis indirectly states the difficulty of implementing the TB control policy and the high burden of the disease in the districts under study, in a general way, which puts the actions of control of TB in a situation of campaigning. 
Submission of the sputum to analysis suggests the possibility of classifying the subjects in TB patients or not. This first classificatory step is determinant to know which patients have the disease and treat them. The signifiers submit it for analysis suggest that the subject, affected by the ideology and medical practices of a dominant paradigm, assumes himself as an expert in the disease and holder of the cure and imagines the patient subject as docile and incapable of identifying with the treatment system he is submitted to.

The practice of testing TB patients for HIV is based on the imagery of the position of the healthcare professional subject affected by the interdiscourse that TB is a disease associated with HIV and by the naturalization of a circulating epidemiological discourse that points to HIV/TB $\mathrm{co}^{-}$ infection as one of the problems of sub-Saharan Africa, and especially of Mozambique ${ }^{(2,4,15,17)}$. The linguistic-discourse marks I test them produce the meaning that testing for HIV helps classifying the patient subject and identifying him as sick with TB and HIV or not, which makes opening files for treatment easier: we open the files. All these actions seek assuring TB control, because they are articulated according to the local reality of the population ${ }^{(7)}$. However, even though classification helps quantifying the cases, assuring guidance to the patients and beginning the treatment, in an indirect way, this classification seems to empower the healthcare professional, and not HS, to monitor and discipline the patient, meaning that it is not focused on determinants and risks that aggravate the patient's situation and put the population's health at risk ${ }^{(18)}$.

The meeting, communication and discussion of treatment actions make TB control easier because they allow the understanding and sharing of messages that produce meanings, signify and exert influence on the behavior of healthcare professionals ${ }^{(19)}$. They also help coordinating the control actions in all the districts in the province. Therefore, the way information is shared can be an important component in engaging professionals in the fight against the disease. In the meetings, gaps and possible solutions to optimize TB control can be identified.

Analyzing the cutouts of this discursive block, it is observed that the healthcare professional subjects' positions are inscribed and identified with the discursive formations that understand communication as important for TB control. Monthly, quarterly, or other meetings ensure that professionals act under the same guidelines and share experiences among them, identifying difficulties and possible solutions. The linguistic-discursive marks we meet with all the health units; quarterly we meet; we hold meetings and discussions; every 30 days we've been having a meeting indicate cohesion and an attempt to develop joint actions to control the disease. It is important to emphasize that the subject positions are affected by the existing interdiscourse regarding the importance of communication in HS actions. However, differences in the periodicity of meetings (quarterly and monthly) show the lack of coordination of activities at the provincial level and the inconsistency of information collection, which may end up affecting the epidemiological information system ${ }^{(3)}$.
The discursive sequences we hold meetings and discussions of our activities to motivate others show the imagery of the subject position of the healthcare professional that imagines that meetings and discussions can lead to motivation and, consequently, to improvement and maintenance of the TB control activities. The discursive sequences until last month we went to the meeting with our laboratory man expose the unspoken, in this case, that the labman has not participated regularly in the discussions. The absence of this professional muffles a lot of information about the real history of the laboratories, that are one of the vital components for detecting cases of TB. The action of going with the laboratory technician produces the meaning that the inclusion of another team member is also important in the control of TB. However, it seems that, in the imagery of the subject that enunciates the sequence under analysis, the laboratory technician is not important, as shown by the linguistic mark until.

As for the discursive block strategies for tuberculosis control, the healthcare professionals reveal local ways of motivating the ACS, characterized mainly by the allocation of material goods such as dishes and capulanas, but, on the other hand, expose in an indirect way the unspoken, the lack of financial compensation for the ACS, which compromises care and control of TB, as shown on the following linguistic marks: the organization called Kulima, brings dishes, capulanas; I offer those to the activists and this motivates them. The lack of a human resources policy that incorporates the ACS as effective members of the healthcare teams can also be seen in those speeches, seeing that they are not paid and have no association with the state, even though their important role in TB control is recognized ${ }^{(3)}$. This situation leads to considering the necessity, on the one hand, of creating a remuneration policy for the ACS, who remarkably contribute to an early detection of TB and to handling the cases and, on the other hand, of valuing all professionals who have a role in developing actions to control $\mathrm{TB}^{(20)}$.

The action of creating communities suggests the adoption of efforts by the healthcare professionals to try to reduce the long distances and offer treatment to the communities further from the sanitary units, thus enunciating the difficulties faced by the professionals and the local solutions they come up to overcome the difficulties experienced in the researched scenario.

Living in the community produces the meaning that the ACS know and understand the historical reality in the context, which enables a greater interaction with the community and, especially, with the patients. The position of the subject affected by the interdiscourse presented in the discursive sequence (...) have a cough for more than a week or two is also notorious. In this context, the naturalization of the circulating meanings about the symptoms of TB can be seen: having a cough for more than two weeks, weight loss, fever, among other signs and symptoms ${ }^{(21)}$. This way, the subject naturalizes the circulating meanings that emphasize the short-term treatment through medication intake, seen as important in the control of TB. The action of searching for the sick is anchored in the subject's imagery that the disease will only be eradicated if all potential hosts are cured. 
The TB control policy in Mozambique gives the healthcare professional authority and legitimacy to look for the patient wherever he is.

It is pointed out that, in an attempt to coordinate activities, the subject moves to other health units of the district, to try to secure the standardization of the activities of TB control. The linguistic marks raise awareness among my colleagues sign a lack of comprehension about the activities to be developed, but also the imagery that being part of the TB control program may imply in an additional remuneration: my colleagues think that being in the TB program is about money.

As for the discursive block involvement of family and community leaders in the TB control it can be noted that the linguistic marks we involve family members; the family members control the patient suggest that the function of controlling the patient, carried out by the healthcare professionals, is also entrusted to family members, to make sure discipline and surveillance are well fortified in order to control the disease. The pact made with the family intends to empower them to monitor and control the patient in order to provide him with treatment ${ }^{(18)}$. The actions of health education the family receives can also be observed: inform the care they should give the patient and the help they should provide him, this educative action, focused in the physical body, is based on the imagery that the family is the center and the driving force to permanently monitor the patient ${ }^{(18)}$.

The presence of a transverse discourse, understood as what crosses and connects together the discursive elements constituted by the interdiscourse as preconstructed ${ }^{(9)}$, is more prominent in the discursive sequences: we (...) talk to the patient (...); we try to know the family history (...) it is already a contract (...) we explain. In these discursive sequences, the individual is constructed as a subject that speaks with the discursive formation he is inserted $\mathrm{in}^{(9)}$. In this case, the subject is inserted in a discursive formation that reinforces the importance of the family in the healing process of the patient. So, the action presented in contact and talk to the patient is one of the steps to negotiate the treatment. The action of asking about the patient's life guarantees that the healthcare professional is aware of any potential threat the patient may present to the family, especially to the children and the elderly, who are more vulnerable to contracting the disease. In this context, the action of administering chemoprophylaxis to those who live with the patient allow eradicating the disease in the family context ${ }^{(2)}$. It is understood, therefore, that the execution of the Direct Observation treatment requires the involvement of the healthcare professional and a primordial technical ability that guarantees an effective relation between health professionals, TB patients and family, which also implies tracing people close to the suspected or confirmed case of $\mathrm{TB}^{(1)}$.

\section{CONCLUSION}

The words of the healthcare professionals produced several meanings that suggest, as Health Surveillance actions, practices that include collecting sputum in the patient's home and sending it to the lab; deployment of the medical team with a microscope for TB testing; and testing for diseases that may be connected to TB to help in TB control.

Despite some recorded advances and the engagement of professionals who carry out actions to control TB, the inconsistencies identified in the speeches show the fragility of the effectiveness of this control. Reinforcing these actions and multiplying them in several parts of the country could help reduce TB. A scenario of a high burden of the disease, with a lack of human resources and of financing and valuing all actors: family, community leaders, patients and professionals engaged in TB control are important factors in the decay of the epidemiological situation of the disease at the researched location. Nevertheless, disease control implies the commitment of the State to the problem of TB and the allocation of more financial, material and human resources to health units, so that Health Surveillance actions are consistently reinforced.

\section{RESUMO}

Objetivo: Analisar os sentidos produzidos sobre as ações de Vigilância em Saúde no controle da tuberculose desenvolvidas por profissionais de saúde em Moçambique. Método: Estudo qualitativo que tem como referencial teórico-metodológico a Análise de Discurso de matriz francesa. Resultados: Participaram do estudo 15 profissionais de saúde, com mais de 1 ano de experiência em ações de controle da doença. Da análise, emergiram quatro blocos discursivos: processo do diagnóstico da tuberculose; reunião, comunicação e discussão do tratamento; estratégias locais para o controle da tuberculose; envolvimento da família e dos líderes comunitários no controle da tuberculose. Conclusão: Os dizeres dos profissionais de saúde sugerem, como ações de Vigilância em Saúde, práticas que incluem a coleta de escarro na residência do paciente e seu encaminhamento ao laboratório; o deslocamento da equipe médica com microscópio para a testagem da tuberculose; e a testagem das doenças que podem estar associadas à tuberculose. Nesse contexto, as ações de Vigilância em Saúde no controle da tuberculose envolvem a valorização de todos os atores: família, líderes comunitários, pacientes e profissionais de saúde.

\section{DESCRITORES}

Tuberculose; Vigilância Sanitária; Moçambique; Enfermagem em Saúde Pública; Serviços de Saúde.

\section{RESUMEN}

Objetivo: Analizar los sentidos producidos sobre las acciones de Vigilancia Sanitaria en el control de la tuberculosis desarrolladas por profesionales sanitarios en Mozambique. Método: Estudio cualitativo que tiene como marco de referencia teórico-metodológico el Análisis de Discurso de matriz francesa. Resultados: Participaron en el estudio 15 profesionales sanitarios, con más de un año de experiencia en acciones de control de la enfermedad. Del análisis surgieron cuatro bloques discursivos: proceso del diagnóstico de la tuberculosis; reunión, comunicación y discusión del tratamiento; estrategias locales para el control de la tuberculosis; involucración de la familia y los líderes comunitarios en el control de la tuberculosis. Conclusión: En las palabras de los profesionales sanitarios sugieren, 
como acciones de Vigilancia Sanitaria, prácticas que incluyen la recolección de esputo en la residencia del paciente y su envío al laboratorio; el desplazamiento del equipo médico con microscopio para la prueba de la tuberculina; y la prueba de las enfermedades que pueden estar asociadas con la tuberculosis. En ese marco, las acciones de Vigilancia Sanitaria en el control de la tuberculosis involucran la valorización de todos los actores: familia, líderes comunitarios, pacientes y profesionales sanitarios.

\section{DESCRIPTORES}

Tuberculosis; Vigilancia Sanitaria; Mozambique; Enfermería en Salud Pública; Servicios de Salud.

\section{REFERENCES}

1. Wikman-Jorgenson PE, Marales-Cartagena A, Llenas-García J, Pérez-Porcuna TM, Hobbins M, Ehmer J, et al. Implementation challenges of a TB programme in rural northern Mozambique: evaluation of 2012-2013 outcomes. Pathog Glob Health. 2015;109(5):221-7.

2. World Health Organization. Global Tuberculosis control [Internet]. Geneva: WHO; 2015. [cited 2016 Jan 27]. Available from: http://apps. who.int/iris/bitstream/10665/191102/1/9789241565059_eng.pdf?ua=1

3. Moçambique. Ministério da Saúde. Relatórios das Actividades Desenvolvidas durante o ano 2014. Maputo: Ministério da Saúde; 2015.

4. García-Basteiro AL, López-Varela E, Manhiça I, Macete E, Alonso PL. Mozambique faces challenges in the fight against tuberculosis. Lancet. 2014;383(9913):2015-6.

5. Melo MA, Bezerra JCB, Puente-palacios KE, Castro AM, Coleta MFD, Coleta JAD, et al. Características Organizacionais da Vigilância Sanitária Municipal e sua Relação com os Indicadores de Saúde. Rev Adm UEG. 2015;6(1):46-66.

6. Hino P, Santos CB, Villa TCS, Bertolozzi MR, Takahash RF. O controle da tuberculose na perspectiva da Vigilância da Saúde. Esc Anna Nery. $2011 ; 15(2): 417-21$.

7. Oliveira CM, Cruz MM. Sistema de Vigilância em Saúde no Brasil: avanços e desafios. Saúde Deb. 2015;39(104):255-67.

8. Orlandi EP. Análise de discurso: princípios e procedimentos. 11ª ed. Campinas: Pontes; 2013.

9. Pêcheux M. Semântica e discurso: uma crítica a afirmação do óbvio. $2^{a}$ ed. Campinas: UNICAMP; 2009.

10. Lagazzi S. Desafios de dizer não. Campinas: Pontes; 1998.

11. Ginzburg C. Mitos, emblemas, sinais: morfologia e história. São Paulo: Companhia das Letras; 2012.

12. Zlauziu F, Floyd k, Well D, Raviglione M. TB deaths rank alongside HIV deaths as top infectious killer. Int J Tuberc Lung Dis. 2016;20(2):1434.

13. Mialhe FL, David HMS. Os discursos dos agentes comunitários de saúde sobre suas práticas educativas. In: Mialhe FL, organizador. O agente comunitário de saúde: práticas edicativas. Campinas: UNICAMP; 2011. p. 83-120.

14. Markuns JF, Montegut AJ. Atenção primária na saúde global. In: Markle WH, Fisher MA, Smego-JR, RA, organizadores. Compreendendo a saúde global. Porto Alegre: AMGH; 2015. p. 216-43.

15. Bos JC, Smalbraak L, Macome AC, Gomes E, Leth FV, Parins JM. TB diagnostic process management of patients in a referral hospital in Mozambique in comparison with the 2007 WHO recommendations for the diagnosis of smear-negative pulmonary TB and extrapulmonary TB. Int Health. 2013;5(4):302-8.

16. Borges MJL, Sampaio AS, Gurgel IGD. Trabalho em equipe e interdisciplinaridade: desafios para efetivação de integralidade na assistência ambiental às pessoas vivendo com HVI/Aids em Pernambuco. Ciênc Saúde Coletiva. 2012;17(1):156-6.

17. Brouwer M, Coelho E, Mosse CD, Feth FV. Implementation of tuberculosis infection prevention and control in Mozambique health care facilities. Int J Tuberc Lung Dis. 2015;19 (1):44-9.

18. Foucault M. Miocrofísica do poder. Rio de Janeiro: Paz e Terra; 2014.

19. Mourão CML, Albuquerque ALMS, Silva APS, Oliveira MS, Fernandes AFC. Comunicação em Enfermagem: uma revisão Bibliográfica. Rev Rene. 2009;10(3):139-45.

20. Crispim JA, Scatolin BE, Silva LMC, Pinto IC, Palha PF, Arcêncio RA. Agente Comunitário de Saúde no controle da tuberculose na atenção primária à saúde. Acta Paul Enferm. 2012;25(5):721-7.

21. Nguyen DTM, Bang ND, Hung NQ, Beasley RP, Hwang LY, Graviss EA. Yield of chest radiograph in tuberculosis screening for HIVinfected persons at a district-level HIV clinic. Int J Tuberc Lung Dis. 2016;20(2):211-7. 